\title{
Mitigating greenhouse gas emissions from New Zealand pasture- based livestock farm systems
}

\author{
Sinead C. LEAHY*, Laura KEARNEY, Andy REISINGER and Harry CLARK \\ ${ }^{1}$ New Zealand Agricultural Greenhouse Gas Research Centre (NZAGRC), Palmerston North, New Zealand \\ *Corresponding author: sinead.leahy@nzagrc.org.nz
}

\begin{abstract}
The reduction of the agricultural greenhouse gases, methane and nitrous oxide is likely to play an important role in New Zealand's transition to a low-emissions economy. A limited range of options currently exists to reduce emissions from pasture-based livestock farming systems. However, several promising options are under development which have the potential to considerably reduce on-farm emissions, such as inhibitors and vaccines. On-farm forestry can be used to offset emissions through carbon sequestration in trees, but more scientifically robust and consistent evidence is needed if soil carbon sequestration is to be used to offset New Zealand's greenhouse gas emissions.
\end{abstract}

Keywords: methane, nitrous oxide, mitigation, soil carbon, forestry, agriculture, greenhouse gas emissions

\section{Introduction}

Under the Paris Agreement on climate change (UN 2015), New Zealand has committed to reducing greenhouse gas (GHG) emissions to 30\% below 2005 levels by 2030 . The Government has also gazetted a 2050 target of $50 \%$ below 1990 levels but is consulting on a revised 2050 target under the Zero Carbon Bill. The Bill proposes separate targets for different greenhouse gases, i.e. a net zero target for carbon dioxide $\left(\mathrm{CO}_{2}\right)$ and nitrous oxide $\left(\mathrm{N}_{2} \mathrm{O}\right)$, and a reduction of between 24 $47 \%$ for methane $\left(\mathrm{CH}_{4}\right)$ by 2050 with a $10 \%$ reduction below 2017 levels by 2030. These targets, if adopted by Parliament, would pose a stern challenge to the agricultural sector.

Carbon dioxide, $\mathrm{CH}_{4}$ and $\mathrm{N}_{2} \mathrm{O}$ are the main GHGs produced in New Zealand. Almost half of New Zealand's $\mathrm{CO}_{2}$ equivalent $\left(\mathrm{CO}_{2} \mathrm{e}\right)$ GHG emissions (48\% in 2017) come from agriculture, comprising $\mathrm{CH}_{4}$ and $\mathrm{N}_{2} \mathrm{O}$. Carbon dioxide equivalent $\left(\mathrm{CO}_{2} \mathrm{e}\right)$ is used for describing different GHGs in a common unit. It is a measure for how much warming a given type and amount of GHG causes over 100 years following its emission, using the equivalent amount of $\mathrm{CO}_{2}$ as the reference. A further $45 \%$ of New Zealand emissions are from $\mathrm{CO}_{2}$ arising from the energy, industry and transport sectors. From 1990 (the base year for national reporting purposes) to 2017, absolute emissions of $\mathrm{CH}_{4}$ and $\mathrm{N}_{2} \mathrm{O}$ from agriculture have increased by $13.5 \%$. However, there has been little change in agricultural emissions since 2008 and emissions reduced by $1 \%$ between 2015 and 2017.

Between 1990 and 2017, the national dairy herd almost doubled in size and increased its emissions by $129 \%$. In contrast, sheep and beef numbers decreased by 52.5 and $21 \%$, respectively, accompanied by reductions of $41 \%$ and $7 \%$ in emissions. An increase of approximately $650 \%$ in the application of nitrogencontaining fertiliser, along with increasing nitrogen deposition via urine and dung from animals, and the resulting increase in $\mathrm{N}_{2} \mathrm{O}$ emissions from agricultural soils, made up approximately $40 \%$ of the total increase in agricultural emissions between 1990 and 2017 (MfE 2019).

Although absolute emissions have increased since 1990, there has been a consistent reduction in emissions per unit of product of approximately $1 \%$ per annum, reflecting increasing animal performance and productivity at farm level. Without this increase in production efficiency, agricultural emissions could have risen by almost $40 \%$ to produce the same amount of meat and milk, instead of the observed $13.5 \%$.

\section{Agricultural GHGs - sources and characteristics}

The main sources of New Zealand agricultural GHGs are illustrated in Figure 1. Methane comes mainly from the digestive system of ruminants produced via a process known as enteric fermentation. There is also a small contribution from manure management. Feed intake is the main influence on how much $\mathrm{CH}_{4}$ a ruminant animal produces. Generally, approximately 21 grams of $\mathrm{CH}_{4}$ are produced per kilogram of dry matter eaten from predominantly pasture-fed livestock. This value varies only slightly across the typical feeds in New Zealand's pastoral systems: fresh pasture (ryegrass and clover); pasture silage; and maize silage (Pickering \& Gibbs 2018). Nitrous oxide emissions come largely from urine patches deposited by ruminants, with smaller amounts coming from dung deposited during grazing, stored manures spread back onto pastures, and from nitrogen $(\mathrm{N})$ fertiliser. Total $\mathrm{N}$ inputs in a farm 
A
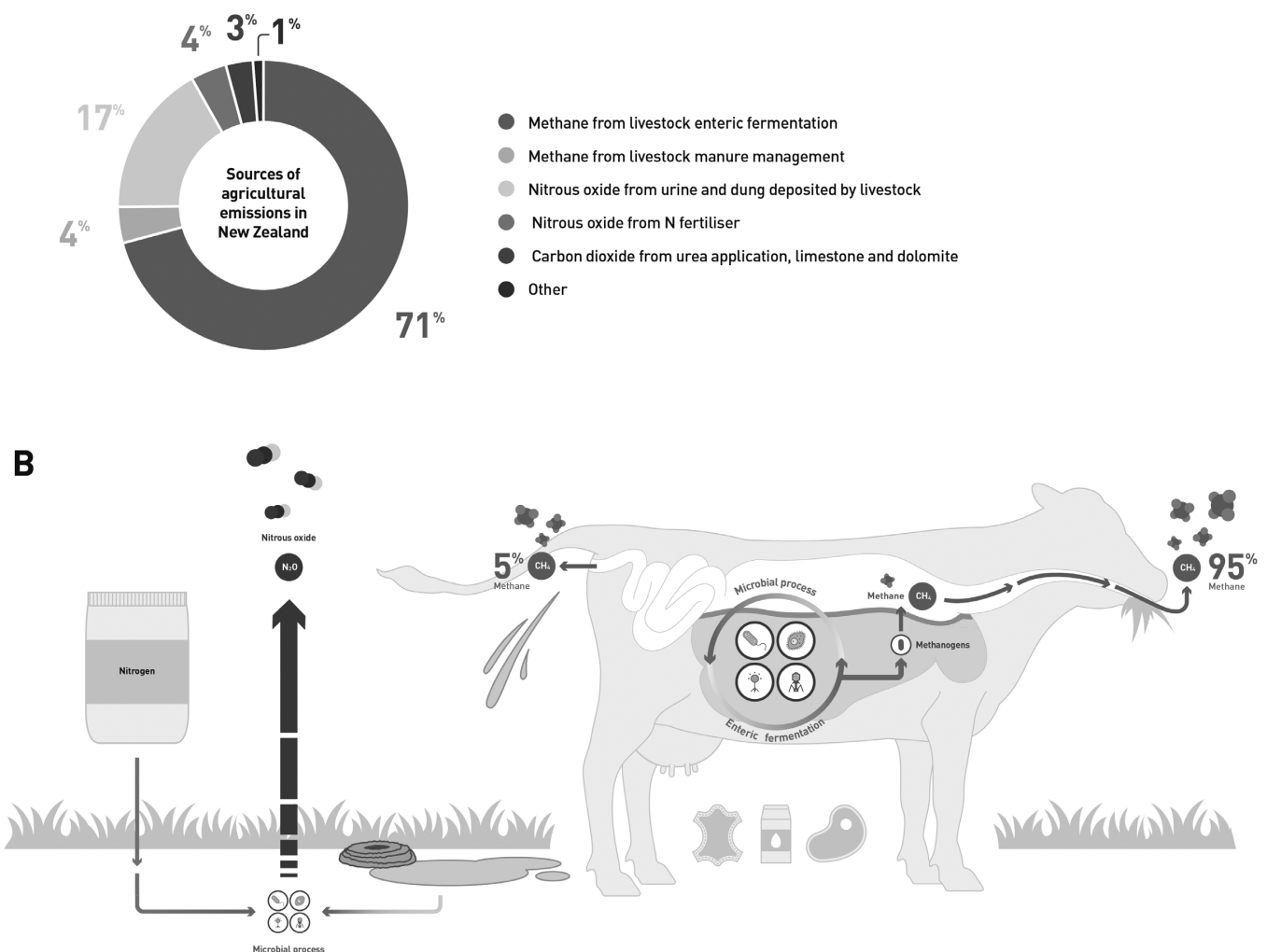

Figure 1 Panel (a) Pie chart showing the breakdown (percentage) of New Zealand's agricultural emissions in 2017; Panel (b) Illustration showing the main sources of agricultural emissions. Enteric fermentation is a digestive process by which a community of microbes present in the forestomach of ruminants (the reticulo-rumen) break down plant material into nutrients that can be used by the animal to produce milk meat and fibre products. Fermentation end products of this process are used by microbes known as methanogens to form methane, which is belched from the animal and released to the atmosphere. Direct emissions of nitrous oxide from soils result primarily from microbially driven nitrification and denitrification processes together with non-biological chemodenitrification. Indirect emissions of nitrous oxide come predominantly from $\mathrm{N}$ lost to the agricultural system e.g. through leaching runoff or atmospheric deposition.

system (and subsequent internal $\mathrm{N}$ cycling through animal excreta) is a key driver for $\mathrm{N}_{2} \mathrm{O}$ emissions.

Methane and $\mathrm{N}_{2} \mathrm{O}$ have different chemical and physical properties and influence the climate in different ways. The lifetime ${ }^{1}$ of $\mathrm{CH}_{4}$ in the atmosphere is relatively short (approximately 12 years); this means that a unit of $\mathrm{CH}_{4}$ emitted today will have decomposed and thus removed from the atmosphere almost entirely within about 50 years. The lifetime of $\mathrm{N}_{2} \mathrm{O}$ in the atmosphere is about 120 years, meaning that it takes more than five hundred years for a unit of $\mathrm{N}_{2} \mathrm{O}$ to be

1 Lifetime refers to the decay constant $t$ for gases following an exponentia decay curve $\left(\mathrm{CH}_{4}(\mathrm{t})=\mathrm{CH}_{4}\right.$ intial $\times \mathrm{e}$-t/t) . In the case of $\mathrm{CH}_{4}$, the decay constant is 12.4 years, which means that after 12.4 years, $63 \%$ of the original methane emission will have decayed, and after another 12.4 years, another $63 \%$ of the remaining methane, etc. After four lifetimes ( $\sim 50$ years) a little over $1 \%$ of the original $\mathrm{CH}_{4}$ emission will remain. Lifetime and half-life (denoting the time when $50 \%$ of a substance has decayed) can be calculated from each other for gases with an exponential decay characteristic. removed entirely from the atmosphere. In this respect, $\mathrm{N}_{2} \mathrm{O}$ and $\mathrm{CO}_{2}$ are very similar since $\mathrm{CO}_{2}$ remains in the atmosphere for many centuries and a fraction even for millennia (Myhre et al. 2013). This is why these two gases are often referred to as long-lived gases. While $\mathrm{CH}_{4}$ and $\mathrm{N}_{2} \mathrm{O}$ are in the atmosphere, they are much more effective at trapping heat than $\mathrm{CO}_{2}$ (approximately 30 and 300 times respectively when assessed over a 100 year time frame). However, these figures do not tell the whole story.

The short life of $\mathrm{CH}_{4}$ means that it does not accumulate in the atmosphere in the same way as $\mathrm{N}_{2} \mathrm{O}$ and $\mathrm{CO}_{2}$ do; a unit of $\mathrm{CH}_{4}$ emitted today to a large extent simply replaces a unit emitted a few decades earlier. If $\mathrm{CH}_{4}$ emissions are constant, their concentration in the atmosphere does not continue to increase but stabilises within 50 years. The same is not true of the long-lived gases since every emission adds 
to the stock of those gases in the atmosphere, and hence their concentration in the atmosphere would continue to rise for many hundreds of years if their emissions are constant. This explains why, globally, the main focus of emissions reduction has to be to reduce the emission of long-lived gases, particularly $\mathrm{CO}_{2}$, to net zero if the global temperature is to be stabilised at any level. By contrast, $\mathrm{CH}_{4}$ emissions do not have to be reduced to zero to prevent further climate change, but the lower $\mathrm{CH}_{4}$ emissions can go, the lower the total amount of warming caused. This explains why there is a proposed separate target for $\mathrm{CH}_{4}$, but also why there is debate about what the target should be (Reisinger 2018a; Reisinger \& Leahy 2019).

Although globally the main focus has to be on reducing $\mathrm{CO}_{2}$ emissions, reductions in both $\mathrm{CH}_{4}$ and $\mathrm{N}_{2} \mathrm{O}$ will help in the global effort to limit anthropogenic climate change. For example, New Zealand is estimated to have contributed a little over 0.0028 degrees Celsius to the observed global warming of about 1 degree Celsius above pre-industrial levels, with our $\mathrm{CH}_{4}$ emissions currently making a bigger estimated contribution to global warming than our cumulative emissions of fossil $\mathrm{CO}_{2}$ and $\mathrm{N}_{2} \mathrm{O}$ combined (Reisinger \& Leahy 2019). Globally, agricultural $\mathrm{CH}_{4}$ emissions reduce by 24$47 \%$ in scenarios that limit warming to 1.5 degrees as envisaged under the Paris Agreement (IPCC, 2018).

While New Zealand farmers are increasingly focused on improving their on-farm environmental sustainability, reducing GHGs has not been a strong focus to date. A recent survey of New Zealand farmers found that only $2 \%$ of respondents know the total GHG emissions from their farms and only $1 \%$ are aware of their per animal emissions (MPI 2019). However, modelling is helping generate a picture of emissions from different New Zealand farm types. A recent study of 382 dairy and 32 sheep and beef farms (AgFirst 2019), found an average 9.6 tonnes of GHG emissions per hectare of $\mathrm{CO}_{2} \mathrm{e}$ for dairy farms and $3.1 \mathrm{t} / \mathrm{ha} \mathrm{CO}_{2} \mathrm{e}$ for sheep and beef farms. The range for dairy was between 3.1-18.8 t/ha $\mathrm{CO}_{2} \mathrm{e}$ while sheep and beef farms had a range between 0.9-5.1 t/ha $\mathrm{CO}_{2} \mathrm{e}$. Average emissions per unit of product for dairy was found to be $8.8 \mathrm{~kg}$ $\mathrm{CO}_{2} \mathrm{e} / \mathrm{kg}$ milk solids (range 4.3-17.2); the average for sheep and beef was $16.0 \mathrm{~kg} \mathrm{CO}_{2} \mathrm{e}$ per kg meat (range 3.8-33.7). These figures are good by international standards, reflecting the efficiency of New Zealand farmers and farming systems. However, most of our competitors are also highly efficient (Clune et al. 2017) and New Zealand will have to continually improve to stay ahead in the marketplace. This paper details our current understanding of some of the mitigation options farmers can consider now and may consider in the future for pasture-based livestock farm systems.

\section{Reducing emissions now}

There are no easy answers to the question 'what can I do to reduce my emissions now?' Recent modelling and expert judgements (Reisinger et al. 2018b, c; AgFirst 2019) identified a variety of mitigation options that exist and could be used to collectively reduce total agricultural $\mathrm{CH}_{4}$ and $\mathrm{N}_{2} \mathrm{O}$ emissions in New Zealand by up to $5-10 \%$ without necessarily reducing on-farm profitability. However, results from implementation of these mitigation options will vary, can be challenging and actual economic outcomes for each farmer will depend on a range of factors. New Zealand farms all differ in terms of landscape, land use, soil characteristics, tree cover, forages, livestock mix and farm management systems. Each farm operates a unique system and finding the best way to reduce $\mathrm{CH}_{4}$ and $\mathrm{N}_{2} \mathrm{O}$ emissions will depend on: the objectives of the farmer; imposed regulations; economic situation; commodity prices; and the skill level required to implement various mitigation options. It is clear, there is no 'one size fits all' technology and any existing mitigation option will need to be tailored to an individual farm.

A critical first step for farmers is to calculate the farm emissions. Unless emissions are known and examined it isn't possible to assess how management and/or system changes will affect emissions. Calculators such as OVERSEER ${ }^{\mathrm{TM}}$ (https://www.overseer.org.nz/) and Lincoln University's Carbon Calculator (http://www. lincoln.ac.nz/Research/Research/RC/AERU/CarbonCalculator/) are available and can be used to estimate GHG emissions. Once emissions are known, there are several actions whereby farmers may be able to reduce GHGs. For the purposes of this paper, the mitigation actions which have been detailed comprehensively by Reisinger et al. (2018b, c) have been broadly grouped and summarised into the following six areas:

\section{(1) Increasing individual animal performance while} reducing stocking rate

Management practices, such as improving animal health, reproduction and pasture quality, and increasing genetic merit/breeding worth of animals can increase performance per animal (e.g. kg milk solids, kg lamb slaughtered per ewe, $\mathrm{kg}$ beef slaughtered per cow). If this increase in animal performance is achieved in combination with reduced stocking rates and reduced farm inputs, this can lower GHG emissions, allowing farmers to maintain total production from fewer animals. Additionally, New Zealand currently has about 1 million breeding beef cows. For some, the option exists to reduce emissions from beef systems by reducing the proportion of breeding beef cows in the overall herd, as well as making greater use of surplus calves from the national dairy herd, thereby reducing total GHG emissions since fewer breeding cows need to be carried. 


\section{(2) Low-emission feeds}

In New Zealand, livestock diets are predominantly grass/legume pasture meaning that the opportunities to reduce emissions by dietary manipulation are, in practice, limited. However, some farmers, particularly in the dairy sector, have been increasing their use of supplementary feeds to improve performance and the chemical makeup of these supplementary feeds can influence emissions. Feeds with higher energy levels (fodder beet, grains) can improve animal performance such that less total feed is needed to reach a given level of milk yield or liveweight gain; if less total feed is consumed as a result, emissions may reduce. Additionally, considerable research has focussed on identifying feeds with low-emitting properties. Some feeds can influence emissions per unit of feed intake. For example, some feeds ferment differently in the rumen and reduce $\mathrm{CH}_{4}$ per unit of feed intake while others have a lower $\mathrm{N}$ concentration such that less $\mathrm{N}$ is excreted onto pastures and $\mathrm{N}_{2} \mathrm{O}$ emissions reduced (see section below for more detailed description of the potential low-emission feeds being investigated in New Zealand).

\section{(3) Less intensive systems}

New Zealand dairy farms operate on a spectrum from low input, relying entirely on grass grown on farm to intensive farm systems where typically about $25-40 \%$ of the total feed is imported to the farm year-round. The mitigation option exists to consider moving to lower stocking rates, feed inputs and consequently milk production and GHG emissions. However, transitioning to lower intensity farming may require considerable management skill to adjust the farm system down while ensuring it remains efficient, economic and climate resilient.

Once-a-day milking is currently practised by $5-10 \%$ of dairy farmers at some stage during lactation and is a potential mitigation option for some. The main effect of reducing milking frequency on emissions is a reduction in daily feed intake per cow and hence reduced emissions. However, the economic impact of reduced production must be carefully considered as costs must be reduced in line with reduced milk income. If animal numbers are increased to compensate for reduced output per cow or milk yield reduction per cow reduces over time, the impacts on GHG emissions will be minor.

\section{(4) Fertiliser use}

Precision farming techniques could, in principle, result in the reduction of fertiliser applied per hectare. Such techniques allow for more targeted, strategic fertiliser use, managing times of application to encourage a better response, improved delivery systems and the use of urease inhibitors to increase the efficacy of fertiliser application. Most of the techniques needed to support more precise application of $\mathrm{N}$ fertiliser already exist and their use is likely to expand in the future. They include sensor technology, targeted application mechanisms at increasingly fine scales, and drone systems. The further development of controlled/slow-release $\mathrm{N}$ fertilisers has the potential to reduce losses by extending the period over which growth supply matches $\mathrm{N}$ demand for plant growth, thus increasing the proportion of $\mathrm{N}$ that is taken up by plants rather than lost through leaching and volatilisation (representing an indirect source of $\mathrm{N}_{2} \mathrm{O}$ ). Precise and strategic application of $\mathrm{N}$ fertiliser is not just dependent on the use of new technologies but relies on farmer knowledge and experience. The key action for precise and strategic application is that $\mathrm{N}$ fertiliser use efficiency is increased so that the total fertiliser $\mathrm{N}$ input can be reduced.

Urease inhibitors are chemical compounds that inhibit the hydrolysis of ammonia from either urine or urea fertiliser, reducing the potential for indirect $\mathrm{N}_{2} \mathrm{O}$ from ammonia deposition. Urease inhibitors are commercially available and around a quarter of urea fertiliser sold in New Zealand is coated with a urease inhibitor. However, the emissions reduction that can be achieved currently through a urease inhibitor is minor because animal urine patches, not nitrogenous fertilisers, are the main source of $\mathrm{N}_{2} \mathrm{O}$ emissions.

\section{(5) Diversifying farm operations}

For some, diversifying farm operations with alternative lower emission land uses (e.g. cropping, horticulture, trees) may be an option. A combination of livestock with some non-livestock enterprises can be used to lower net emissions. Horticulture and arable cropping have lower GHG emissions per hectare than dairy and, in most cases, also lower than beef and sheep systems. Many sheep and beef farms integrate forestry into their overall farm system, either permanent stands for biodiversity and soil protection, or plantation forests as a separate revenue stream. For some farming systems, land-use diversification may be the most practical option available for reducing emissions significantly while also providing increased resilience against market and climate fluctuations. However, making major changes in land use has physical, financial, labour and market constraints and, with the exception of forestry in some regions (see below for a more detailed discussion), is likely to take place relatively slowly.

\section{(6) Manure management}

Emissions related to the management of livestock manure (collected in milking sheds, stand-off and feeding pads) arise in the form of $\mathrm{CH}_{4}$ from anaerobic storage of manure, and in the form of $\mathrm{N}_{2} \mathrm{O}$ from 
volatilisation of nitrogen contained in manure, and $\mathrm{N}_{2} \mathrm{O}$ when manure is spread back onto soils. Options to reduce manure emissions exist through capturing $\mathrm{CH}_{4}$ produced in anaerobic ponds via bio-digestors, aeration of the pond to reduce $\mathrm{CH}_{4}$ and by managing the storage and strategic spreading of manure to minimise $\mathrm{N}_{2} \mathrm{O}$ emissions. For example, timing the spreading of stored manures to coincide with dry conditions. It is wellestablished that the wetter the soil, the greater the fraction of $\mathrm{N}$ that is turned into $\mathrm{N}_{2} \mathrm{O}$.

\section{Reducing emissions in the future}

Achieving large reductions in agricultural emissions, particularly those from livestock, will require new technological innovations. Without new technologies, land use change on a substantial scale will be needed. Several emerging mitigation options are under development and could be available in New Zealand within the next decade (Table 1). These technologies will need to be acceptable to regulators, overseas markets, New Zealand farmers and the public.

\section{Rumen methane inhibitors}

$\mathrm{ACH}_{4}$ inhibitor is a chemical compound that suppresses the activity of the microorganisms (methanogens) that produce $\mathrm{CH}_{4}$ in the rumen. To be most effective, an inhibitor needs to suppress the activity of the methanogens continuously during the digestive process. An inhibitor could be delivered as a feed additive or as a bolus inserted into the rumen. 3-Nitrooxypropanol (3-

Table 1 List of emerging GHG mitigation options and estimate of timelines and mitigation potential.

\begin{tabular}{|c|c|c|}
\hline Technology & $\begin{array}{l}\text { Potentially } \\
\text { available }\end{array}$ & $\begin{array}{l}\text { Possible } \\
\text { mitigation }\end{array}$ \\
\hline \multicolumn{3}{|l|}{ Methane inhibitor } \\
\hline 3-NOP & $1-5$ years & $30+\%$ \\
\hline Others & $5-10$ years & $30+\%$ \\
\hline Methane vaccine & $>10$ years & $30 \%$ \\
\hline Low methane emitting sheep & $2-3$ years & $5-10 \%$ \\
\hline Low methane emitting dairy cattle & $>$ 5years & $10 \%$ \\
\hline \multicolumn{3}{|l|}{ Low emission feeds* } \\
\hline Forage rape & Now & $\sim 30 \%$ \\
\hline Fodder beet & Now & $\sim 20 \%$ \\
\hline Plantain & Now (?) & \\
\hline New nitrification inhibitors & 3-5 years & $50+\%$ \\
\hline
\end{tabular}

*Some NZ farmers already feed their animals using forage rape fodder, beet and plantain; however work is still on-going to quantify and validate the impact these feeds have on GHG emissions.
NOP) is a promising $\mathrm{CH}_{4}$ inhibitor (Duin et al. 2016) developed by DSM Nutritional Products and expected to be commercially available in some countries within the next two years. 3-NOP in its current formulation has been developed to work in Total Mixed Ration (TMR) farm systems and has been shown to result in consistent reductions of $\mathrm{CH}_{4}$ production by around $30 \%$ (Dijkstra et al. 2018) without compromising the productive performance of the animal (Jayanegara et al. 2018). However, for 3-NOP to work effectively it must be present in every mouthful of feed and thus its ability to reduce emissions in grazing systems is limited. However, research into new formulations and delivery methods are in progress and it is likely that new products with increased efficacy for grass-based systems will become available.

New Zealand research has also identified several inhibitor compounds that may be more suitable for pastoral grazing systems. These compounds are under investigation but unlikely to be available in New Zealand before 2025 .

\section{Methane vaccine}

Vaccination against rumen methanogens could theoretically reduce $\mathrm{CH}_{4}$ emissions by inducing antibodies in saliva which enter the rumen and impair the ability of methanogens to produce $\mathrm{CH}_{4}$. It is assumed that a methane vaccine could achieve a similar reduction level on New Zealand farms as observed with inhibitors, around $30 \%$. Research into a $\mathrm{CH}_{4}$ vaccine remains in the development phase and has not yet demonstrated a reduction in $\mathrm{CH}_{4}$ emissions from animals, which is the minimum proof of concept. However, research has shown that antibodies are created by host animals, antibodies can be detected in saliva and in the rumen, antibodies against specific methanogens have been shown to suppress these species in pure cultures in the laboratory, and genome sequencing of methanogens have identified targets that could be used to stimulate antibody production (Wedlock et al. 2013; Subharat et al. 2015; Leahy et al. 2010; Leahy et al. 2013). Creating a vaccine that is delivered via saliva and supress a microbe that is a normal resident of the rumen environment is technically very difficult. However, a $\mathrm{CH}_{4}$ vaccine is expected to be applicable to all ruminant species and be an excellent practical mitigation approach for grazing ruminants. Researchers to date have not found any reason why a $\mathrm{CH}_{4}$ vaccine could not be produced. Once a prototype vaccine has been shown to work, it is expected that it would be a further seven years to market.

\section{Breeding low-emission animals}

Sheep vary naturally in the amount of $\mathrm{CH}_{4}$ they produce for every $\mathrm{kg}$ of dry matter they eat, and this trait is heritable (Pinares-Patino et al. 2013). Animal 
characteristics controlling feed particle retention time (Pinares-Patino et al. 2003) and rumen volume (Goopy et al. 2014; Bain et al. 2014) are likely to contribute to this trait, as are differences in rumen microbial communities (Kittelmann et al. 2014) and expression of microbial genes involved in the production of $\mathrm{CH}_{4}$ (Shi et al. 2014). Currently, $\mathrm{CH}_{4}$ emissions between high- and low-emission rams differ by approximately $10 \%$ after three generations of selection with no adverse effects on major production traits. Existing high- and low-emissions flocks are being maintained in New Zealand and their emissions continue to diverge. Genomic markers have been identified (Jonker et al. 2018) and are being used to incorporate the low emission trait into breeding indices. Industry trials are underway to evaluate the benefits of incorporating the low $\mathrm{CH}_{4}$ trait into the New Zealand Sheep Improvement Selection System.

Cattle show a similar natural variation in their $\mathrm{CH}_{4}$ emissions per unit of dry matter intake. However, to date, work in New Zealand has been limited due to the cost and difficulty in directly measuring the large numbers of animals required to establish a selection programme. Researchers are attempting to develop a variety of proxy indicators of $\mathrm{CH}_{4}$ production to enable cheap and rapid identification of low-emitting animals (Negussie et al. 2017). In New Zealand, work will start in early 2020 to measure phenotypic variability in $\mathrm{CH}_{4}$ emissions from dairy bulls.

\section{Low-emission feeds}

Methane. Supplementary feeds relevant to New Zealand that have been shown to reduce the amount of $\mathrm{CH}_{4}$ produced by an animal per unit of feed eaten include forage rape and fodder beet (NZAGRC/PGgRc 2019). Compared to ryegrass/white clover diets, $100 \%$ rape diets consistently reduce emissions by an average $30 \%$. Furthermore, the reduction in emissions is proportional to the proportion in the diet. However, there is some evidence that feeding of forage rape could result in increased $\mathrm{N}_{2} \mathrm{O}$ emissions, and this is currently being investigated. Fodder beet is an increasingly popular crop, particularly in the South Island of New Zealand and research indicates that fodder beet can reduce $\mathrm{CH}_{4}$ emissions by around $20 \%$ but only at very high levels of inclusion in the diet (greater than $70 \%$ ), which is challenging to implement from an animal welfare perspective. The results are also somewhat variable and, in some circumstances, could be the result of short-term digestive disruptions rather than genuine long-term emission reductions. Maintaining high levels of fodder beet in the diet requires careful management and may not be achievable in many farm systems. Research is still on-going to quantify and validate the impact these feeds have on GHG emissions.
Nitrous oxide. Results to date on the impacts of different plants on $\mathrm{N}_{2} \mathrm{O}$ emissions and on the potential underlying mechanisms for reductions are not always conclusive (de Klein et al. 2019). Supplementary feeds such as maize and fodder beet have nitrogen concentrations that are lower than the standard grass/clover diet. Increasing the proportion of these feeds in the diet could in some instances lower total dietary $\mathrm{N}$ concentration and $\mathrm{N}$ excretion and reduce $\mathrm{N}_{2} \mathrm{O}$ emissions. A plantain (Plantago lanceolata L.) cultivar is also showing promise for reducing both nitrate leaching and GHG emissions (Luo et al. 2018). An intensive research effort is currently underway to confirm the efficacy of plantain to reduce GHG emissions and understand how best to integrate it into New Zealand farm systems.

\section{Nitrification inhibitors}

Nitrification inhibitors are chemical compounds that inhibit the formation of nitrate in the soil, and thus the potential for $\mathrm{N}_{2} \mathrm{O}$ production. Nitrification inhibitors are available and include e.g. 2-chloro-6(trichloromethyl)-pyridine (nitrapyrin), dicyandiamide (DCD) and 3, 4-dimethylpyrazole phosphate (DMPP)). The nitrification inhibitor, DCD has been used both as a coating on fertilisers and as a spray on pastures in New Zealand. Several studies have shown that both $\mathrm{N}_{2} \mathrm{O}$ emissions and nitrate leaching from urine patches can be significantly mitigated by treating grazed pasture with DCD, with potential reductions in $\mathrm{N}_{2} \mathrm{O}$ from urine patches reported between $61-73 \%$ and reductions in nitrate leaching from a grazed pasture by $21-56 \%$ (reviewed by $\mathrm{Li}$ et al. 2013, Clough et al. 2011). However, the discovery of residues in milk in 2011 led to its withdrawal from use in New Zealand and as such is not currently used by NZ livestock farmers. Although DCD has been used in cropping for decades and is recognised as non-toxic, there is no declared Maximum Residue Limit under the Codex Alimentarius (international food safety standards), hence a default limit of zero residue applies. A process is underway to identify a threshold level of residues of compounds (such as DCD and others) with a very low toxicology that could be introduced to the Codex Alimentarius, which would allow re-introduction of DCD for commercial use. However, given the previous market reaction to the discovery of DCD residues in milk, there may still be reservations about its reintroduction, even if the international standards are modified (Eckard \& Clark 2018). Researchers in New Zealand are looking to identify and commercialise new nitrification inhibitors that have a wider availability, lower cost, and equally low or lower risk of residues as DCD. A suite of promising compounds has been identified and testing has begun to deliver proof of concept in the field. 


\section{Offsetting GHG emissions on farms}

Trees. Trees absorb $\mathrm{CO}_{2}$ from the atmosphere and store the carbon in trunks, branches, leaves, and roots. The potential exists for more trees to be planted in New Zealand's pastoral landscape to offset emissions. However, when trees are harvested the $\mathrm{CO}_{2}$ stored will be released, in many cases over a relatively short period of time. If a harvested forest is replanted, the process of carbon accumulation will begin again but this only replaces the carbon being released from the first harvest. Therefore, a plantation forest can only be counted as an offset once. In contrast, long-lived (often native) forests are different as they can continue to absorb carbon for hundreds of years, but usually at a much lower rate than short-rotation plantations. Trees are, therefore, not a permanent offset of emissions unless they are being planted as a permanent forest. If shortrotation forests are used as a primary mitigation approach, it implies an increasing amount of New Zealand being afforested if gross emissions are not reduced concurrently. This is currently a cause of some concern by various commentators because of the wider environmental, social and economic implications associated with the different nature and timing of employment in forestry compared with farm systems, which could have flow-on effects on wider rural communities.

Soil Carbon. Soils are a sink of atmospheric $\mathrm{CO}_{2}$ as plantderived carbon is incorporated into stable soil organic matter. Increasing soil organic carbon has multiple benefits; e.g. improved nutrient supply; improved water-holding capacity; and reduced atmospheric $\mathrm{CO}_{2}$ concentration. New Zealand soils generally contain high stocks of soil carbon (>100 tonnes per ha to a depth of $30 \mathrm{~cm}$ ) and, thus, the scope to increase soil carbon stocks may be limited (Whitehead et al. 2018).

Measuring soil carbon change is challenging. Carbon stocks are highly variable within a farm and even within a paddock. They are also influenced by environmental factors and so fluctuate over time. They also tend to increase slowly but can be lost rapidly. Measuring a small change against a large and variable background value is technically extremely difficult and researchers have only recently begun to identify the most robust and accurate methodologies for this.

Data on whether New Zealand agricultural soils are gaining or losing soil carbon is sparse (Schipper et al. 2017). It is difficult, therefore, to conclude with any certainty whether New Zealand soils on average are gaining or losing soil carbon. Evidence to date on New Zealand soils suggest that dairy soils on flat land are losing soil carbon, beef/sheep farms on medium slopes are gaining soil carbon and irrigated soils have lower soil carbon than non-irrigated soils (Mudge et al. 2016). It is also difficult to identify specific management practices that can reliably increase rates of soil carbon accumulation; there is plenty of anecdotal evidence that soil carbon stocks can be increased by various management approaches but hard evidence from long-term trials is lacking. More robust and consistent scientific evidence is needed if soil carbon is to be used to offset GHG emissions. Research is currently underway to develop methodologies that could be used to benchmark and monitor soil carbon sequestration at both the national and farm level.

\section{Conclusions}

New Zealand's agricultural emissions will need to be reduced in the coming decades if New Zealand is to meet its current and signalled international and national commitments on mitigating climate change. There are some actions that farmers can take now, for example estimating on-farm emissions and examining how some already-identified changes in farm practice can reduce emissions is an essential first step. This approach has the potential to reduce emissions by up to $10 \%$ on some farms. However, the main opportunities to reduce farm emissions significantly will rely on technological innovations that are expected to emerge in the next decade. Most of those should be able to be captured by farm-level GHG calculation tools that will need to be developed as part of any farm-level climate policy. There is the potential to offset on-farm emissions via land-use change, particularly forestry, but this brings its own challenges. Increasing soil carbon stocks offers potential but realising this potential in New Zealand's already well managed grasslands could be difficult. Although reduction of agriculture greenhouse gases will be challenging, the New Zealand agricultural sector has always been innovative, quietly creating solutions to the inevitable difficulties of primary production. This innovation will be needed to ensure New Zealand's reputation as one of the world's most efficient producers of high-quality food continues.

\section{ACKNOWLEDGEMENTS}

This paper was supported by the New Zealand Agricultural Greenhouse Gas Research Centre (NZAGRC).

\section{REFERENCES}

AgFirst. 2019. Mitigation and cost of on-farm greenhouse gas emissions. Accessed: 07/07/19 from: https:// www.agfirst.co.nz/wp-content/uploads/2019/05/ Mitigation-of-on-farm-GHG-Emissions-FINAL.pdf

Bain W, Bezuidenhout L, Jopson N, Pinares-Patino C, McEwan J. 2014. Rumen differences between sheep identified as being low or high methane emitters. Proceedings of 10th World Congress of Genetics applied to Livestock Production 39, Vancouver, BC, Canada. 
Clough TJ, Kelliher FM, Clark H, van der Weerden TJ. 2011. Incorporation of the nitrification inhibitor DCD into New Zealand's 2009 National Inventory. MAF Technical Paper No: 2011/92. Accessed 30/08/19 from: https://mpigovtnz.cwp.govt.nz/ dmsdocument/2949/direct

Clune S, Crossin E, Verghese K. 2017. Systematic review of greenhouse gas emissions for different fresh food categories. Journal of Cleaner Production 140: 766-783.

De Klein CAM, van der Weerden TJ, Luo J, Cameron KC, Di HJ. 2019. A review of plant options for mitigation nitrous oxide emissions from pasturebased systems. New Zealand Journal of Agricultural Research https://doi.org/10.1080/00288233.2019.16 14073

Dijkstra J, Bannink A, France J, Kebreab E, van Gasttelen S. 2018. Antimethanogenic effects of 3-nitrooxypropanol depend on supplementation dose, dietary fiber content, and cattle type. Journal of Dairy Science 101: 9041-9047.

Duin EC, Wagner T, Shima S. Prakash D, Cronin B, Yanez-Ruiz DR, Duval S, Rumbeli R, Stemmier RT, Thauer RK, Kindermann M. 2016. Mode of action uncovered for the specific reduction of methane emissions from ruminants by the small molecule 3-nitrooxypropanol. Proceedings of the National Academy of Sciences of the United States of America 113: 6172-6177.

Eckard RJ, Clark H. (2018) Potential solutions to the major greenhouse-gas issues facing Australasian dairy farming. Animal Production Science. https:// doi.org/10.1071/AN18574

Goopy JP, Donaldson A, Hegarty R, Vercoe PE, Haynes F, Barnett M, Oddy VH. 2014. Low-methane yield sheep have smaller rumens and shorter rumen retention time. British Journal of Nutrition 111: 578585.

IPCC. 2018. Global Warming of $1.5^{\circ} \mathrm{C}$. An IPCC special report on the impacts of global warming of $1.5^{\circ} \mathrm{C}$ above pre-industrial levels and related global greenhouse gas emission pathways, in the context of strengthening the global response to the threat of climate change, sustainable development, and efforts to eradicate poverty. [Masson-Delmotte V, Zhai P, Pörtner H-O, Roberts D, Skea J, Shukla PR, Pirani A, Moufouma-Okia W, Pidcock CPR, Connors S, Matthews JBR, Chen Y, Zhou X, Gomis MI, Lonnoy E, Maycock T, Tignor M, Waterfield T. (Eds.)]. Intergovernmental Panel on Climate Change, Geneva.

Jayanegara A, Sarwono KA, Kondo M, Marsui H, Ridla M, Laconi EB, Nahrowi. 2018. Use of 3-nitrooxypropanol as feed additive for mitigating enteric methane emissions from ruminants: a meta- analysis. Italian Journal of Animal Science 17: 650656.

Jonker A, Hickey SM, Rowe SJ, Janssen PH, Shackell GH, Elmes S, Bain WE, Wing J, Greer GJ, Bryson B, MacLean S, Dodds KG, Pinares-Patino CS, Young EA, Knowler K, Pickering NK, McEwan JC. 2018. Genetic parameters of methane emissions determined using portable accumulation chambers in lambs and ewes grazing pasture and genetic correlations with emissions determined in respiration chambers. Journal of Animal Science 8: 3031-3042.

Kittelmann S, Pinares-Patino CS, Seedorf H, Kirk MR, Ganesh S, McEwan JC, Janssen PH. 2014. Two different bacterial community types are linked with the low-methane emission trait in sheep. PLoS One 9: e103171.

Leahy SC, Kelly WJ, Altermann E, Ronimus RS, Yeoman CJ, Pacheco DM, Li D, Kong Z, McTavish S, Sang C, Lambie SC, Janssen PH, Dey D, Attwood GT. 2010. The genome sequence of the rumen methanogen Methanobrevibacter ruminantium reveals new possibilities for controlling ruminant methane emissions. PLoS One 5:e8926.

Leahy SC, Kelly WJ, Ronimus RS, Wedlock N, Altermann E, Attwood GT. 2013. Genome sequencing of rumen bacteria and archaea and its application to methane mitigation strategies. Animal 7(s2): 235-243.

Li D, Watson CJ, Yan MJ, Lalor S, Rafique R, Hyde B, Lanigan G, Richards KG, Holden NM, Humphreys J. 2013. A review of nitrous oxide mitigation by farm nitrogen management in temperate grassland-based agriculture. Journal of Environment Management 128: 893-903.

Luo J, Balvert SF, Wise B, Welten B, Ledgard SF, de Klein CAM, Lindsey S, Judge A. 2018. Using alternative forage species to reduce emissions of the greenhouse gas nitrous oxide from cattle urine deposited onto soil. Science of the Total Environment 610-611:1271-1280.

Ministry for the Environment (MfE). 2019. New Zealand's greenhouse gas inventory. Accessed: 07/07/19 from: https://www.mfe.govt.nz/sites/ default/files/media/Climate\%20Change/nzgreenhouse-gas-inventory-2019.pdf

Ministry for Primary Industries (MPI). 2019. Climate issues facing farmers. Accessed: 07/07/19 from: https://www.mpi.govt.nz/dmsdocument/33747climate-issues-facing-farmers-sustainable-landmanagement-and-climate-change-researchprogramme

Mudge PL, Kelliher FM, Knight TL, O'Connell D, Fraser S, Schipper LA. 2016. Irrigating grazed pasture decreases soil carbon and nitrogen stocks. Global Change Biology 23: 845-954. 
Myhre G, Shindell D, Bréon F.-M, Collins W, Fuglestvedt J, Huang J, Koch D, Lamarque J.F, Lee D, Mendoza B, Nakajima T, Robock A, Stephens G, Takemura T, Zhang H. 2013. Chapter 8: Anthropogenic and Natural Radiative Forcing. In: Climate Change 2013: The scientific basis. Contribution of Working Group $I$ to the 5th Assessment Report of the Intergovernmental Panel on Climate Change. Stocker TF, Qin D, Plattner G-K, Tignor M, Allen SK, Boschung J, Nauels A, Xia Y, Bex V, Midgley PM. Eds. Cambridge University Press, Cambridge, UK.

Negussie E, de Haas Y, Dehareng F, Dewhurst RJ, Dijkstra J, Gengler N, Morgavi DP, Soyeurt H, van Gastelen S, Yan T, Biscarini F. 2017. Large-scale indirect measurements for enteric methane emissions in dairy cattle: A review of proxies and their potential for use in management and breeding decisions. Journal of Dairy Science 100: 2433-2453.

NZAGRC/PGgRc. 2019. Factsheet: Low greenhouse gas feeds. Accessed: 15/07/2019 from: https:// www.nzagrc.org.nz/methane listing 582 reducingnew-zealands-agricultural-greenhouse-gases-lowgreenhouse-gas-feeds.html

Pickering A, Gibbs J. 2018. Methodology for calculation of New Zealand's agricultural greenhouse gas emissions. Version 4. MPI Technical Paper No: 2018/69. Accessed 27/08/19 from: https:// www.mpi.govt.nz/dmsdocument/13906-detailedmethodologies-for-agricultural-greenhouse-gasemission-calculation

Pinares-Patino CS, Ulyatt MJ, Lassey KR, Barry TN, Holmes CW. 2003. Rumen function and digestion parameters associated with differences between sheep in methane emissions when fed chaffed lucerne hay. The Journal of Agricultural Science 140: 205-214.

Pinares-Patino CS, Hickey SM, Young EA, Dodds KG, MacLeanS, Molano G, Sandoval E, Kjestrup H, Harland R, Hunt C, Pickering NK, McEwan JC. 2013. Heritability estimates of methane emissions from sheep. Animal 7(s2): 316-321.

Reisinger A, Leahy SC. 2019. Scientific aspects of New Zealand's 2050 emission targets. Accessed: 07/07/19 from: https://www.nzagrc.org.nz/policy listing 593 scientific-aspects-of-new-zealands-2050-emissiontargets.html

Reisinger A. 2018a. The Contribution of Methane Emissions from New Zealand Livestock to Global
Warming. Report to the Parliamentary Commissioner for the Environment Accessed 23/08/19 from: https:// www.pce.parliament.nz/media/196482/contributionof-methane-emissions-from-nz-livestock-to-globalwarming.pdf

Reisinger A, Clark H, Journeaux P, Clark D, Lambert G 2018b. On-farm options to reduce agricultural GHG emissions in New Zealand. Accessed 07/07/19 from:

https://www.mpi.govt.nz/dmsdocument/32158-bergcurrent-mitigaiton-potential-final

Reisinger A, Clark H, Abercrombie R, Aspin M, Ettema P, Harris M, Hoggard A, Newman M, Sneath G 2018c. Future options to reduce biological GHG emissions on-farm: critical assumptions and national-scale impact. Accessed 07/07/19 from: https://www.mpi. govt.nz/dmsdocument/32128-berg-report-futureoptions-final-dec-2018

Schipper LA, Mudge PL, Kirschbaum MUF, Hedley CB, Golubiewski NE, Smaill SJ, Kelliher FM. 2017. A review of soil carbon change in New Zealand's grazed grasslands. New Zealand Journal of Agricultural Research 60: 93-118.

Shi W, Moon CD, Leahy SC, Kang D, Froula J, Kittelmann S, Fan C, Deutsch S, Gagic D, Seedorf H, Kelly WJ, Atua R, Sang C, Soni P, Li D, PinaresPatino CS, McEwan JC, Janssen PH, Chen F, Visel A, Wang Z, Attwood GT, Rubin EM. 2014. Methane yield phenotypes linked to differential gene expression in the sheep rumen microbiome. Genome Research 24: 1517-1525

Subharat S, Shu D, Zheng T, Buddle BM, Kaneko K, Hook S. 2016. Vaccination of sheep with a methanogen protein provides insight into levels of antibody in saliva needed to target ruminal methanogens. PLoS ONE 11: e0159861.

UN 2015. Paris Agreement. Accessed: 23/08/2019 from: https://unfccc.int/sites/default/files/english paris_agreement.pdf

Wedlock DN, Janssen PH, Leahy SC, Shu D, Buddle BM. 2013. Progress in the development of vaccines against rumen methanogens. Animal 7(s2): 244-252.

Whitehead D, Schipper LA, Pronger J, Moinet GYK, Mudge PL, Calvelo Pereira R, Kirschbaum MUF, McNally SR, Beare MH, Camps-Arbestain M. 2018. Management practices to reduce losses or increase soil carbon stocks in temperate grazed grasslands: New Zealand as a case study. Agriculture, Ecosystems \& Environment 265: 432-443. 
